\title{
ANALYSIS OF GENE AMPLIFICATION IN PAPILLARY THYROID CARCINOMAS
}

\author{
Aleksandar Milićević, Dragan Mihailović, Žaklina Mijović
}

\begin{abstract}
Thyroid cancer is the most common endocrine malignancy and its rate has been steadily increasing all over the world. Papillary thyroid carcinoma (PTC) represents the most common histological subtype of thyroid cancer, accounting for about $75-85 \%$ of the cases. Until now, the mechanisms underlying the tumorigenesis of PTC still remain unclear.

To estimate BRAF and MYC gene amplifications in papillary thyroid carcinomas by FISH analysis and their link with the development of $\mathrm{T} 1$ tumor stage and their possible role in etiopathogenesis of this disease through chronic activation of MAPK pathway.

Tumor tissue specimens from 10 female patients with PTC were analysed by immunohistochemistry (CK19 and Ki67) and FISH analysis. FISH probes were applied on $5 \mu \mathrm{m}$ thick histological sections and covered with glass and sealed with rubber cement. After denaturation at $75^{\circ} \mathrm{C}$ for 5 min, hybridisation process at $37^{\circ} \mathrm{C}$ during $3 \mathrm{~h}$ was done. After washing, DAPI containing mounting medium was applied.

In all tumor nuclei two signals of BRAF and two signals of MYC were found, indicating that gene amplifications were not found in the study group.

Although observed at a low number of patients, amplification of BRAF and MYC genes was not involved in PTC tumorigenesis in the development of T1 tumor stage.
\end{abstract}

Acta Medica Medianae 2020;59(1):31-35.

Key words: papillary thyroid carcinoma, gene amplification, BRAF, MYC, immunohistochemistry, T1 tumor stage

Centre of Pathology, Clinical Center of Niš, Serbia

Contact: Aleksandar Milićević

48 Dr. Zoran Djindjić Blvd., 18000 Niš, Serbia

E-mail: ackom88@gmail.com

\section{Introduction}

Thyroid cancer is the most common endocrine malignancy and its rate has been steadily increasing all over the world. Papillary thyroid carcinoma (PTC) represents the most common histological subtype of thyroid cancer, accounting for about $75-85 \%$ of the cases. Until now, surgical strategy is the major treatment for patients with thyroid cancer, due to its high resistance to standard chemotherapy. However, the extensive resection, postoperative recurrence and metastasis may lead to limited therapeutic effects and poor outcomes (1).

Thyroid cancer mutations develop most often in genes encoding components of the MAPK/ERK and PI3K/AKT pathways (2). In PTCs, the most common mutations are BRAF mutations, which were reported in $40-90 \%$ of cases from various geographical areas. RET/PTC rearrangements are the second most common genetic alteration in PTC (3). On the other hand, RAS mutations have increased sharply, and RET/PTC rearrangements have steadily decreased over the years (4). CMYC regulates approximately $15 \%$ of human genes and is involved in up to $20 \%$ of all human cancers. Reports discussing CMYC protein expression in thyroid carcinomas are limited, with controversies pertaining to CMYC expression patterns noted in the literature.

For well differentiated types of thyroid carcinomas (PTC, FC, and OvFC), there was a nonsignificant trend toward lower CMYC expression from stages pT1 through pT3 (5).

From the clinical point of view, $10 \%$ to $15 \%$ of patients with this carcinoma exhibit poor prognosis, related to still insufficiently identified features of tumor biology which may be uncovered by further expression profiling (6).

Until now the mechanisms underlying the tumorigenesis of PTC still remain unclear, and prediction of disease progression is a great challenge for PTC cases. 


\section{Aim}

The aim of this study was to investigate BRAF and MYC gene amplifications in papillary thyroid carcinomas by FISH analysis in T1 tumor stage and their possible role in etiopathogenesis of this disease through chronic activation of MAPK pathway.

\section{Materials and methods}

\section{Patients}

In the current study, PTC tissues and adjacent normal tissues specimens were collected from 10 female patients who underwent thyroid surgery in Clinical Center of Niš, Serbia. All of the patients were pathologically diagnosed with PTC according to World Health Organization classification, and the tissues specimens were reviewed by two pathologists. All of the patients were diagnosed with T1 stage, without lymph node metastases.

\section{Immnohistochemical analysis}

Formalin-fixed and paraffin-embedded tumor sections (4-5 $\mu \mathrm{m})$ were made for immunohistochemical analysis. Slides set aside for immunohistochemical evaluation after deparaffinization and endogenous peroxidase blocking ( $3 \%$ solution of $\mathrm{H}_{2} \mathrm{O}_{2}$ for $15 \mathrm{~min}$ ) were submitted to microwave treatment (20 min at 620 Win 0.01 M citrate buffer, $\mathrm{pH} 6.0$ ). MIB-1 monoclonal antibody for Ki-67, dilution 1:100, and RCK108 monoclonal antibody for cytokeratin 19
(DAKO, Glostrup, Denmark), was applied for 60 min at room temperature. Immunohistochemical staining was performed by the streptavidin-biotin method using an LSAB kit (DAKO, Glostrup, Denmark) according to the manufacturer's instructions (LSAB Kit, DAKO, Glostrup, Denmark). The chromogen was 3.3'-diaminobenzidine (DAB). Tissue sections were lightly counterstained with Mayer's hematoxylin (Merck, Germany). During the tissue staining, positive and negative control samples were simultaneously stained.

\section{FISH analysis}

Formalin fixed paraffin embedded tissue from 10 patients with papillary thyroid carcinomas were screened for gene amplification. For BRAF gene (7q34) locus specific SureFish BRAF-CN orange-red probe and chromosome 7 centromere locus specific SureFISH green probe were used (Agilent Technologies, West Cedar Creek, USA). For MYC gene (8q24.21) locus specific SureFish MYC red probe, and chromosome 8 centromere locus specific SureFISH green probe were used (Agilent Technologies, West Cedar Creek, USA).

After deparaffinization and denaturation at $80{ }^{\circ} \mathrm{C}$ during $10 \mathrm{~min}$, hybridisation process at $45^{\circ} \mathrm{C}$ during $2 \mathrm{~h}$ was done. FISH probes were applied on 5 $\mu \mathrm{m}$ thick histological sections and covered with glass and sealed with rubber cement. After washing, DAPI containing mounting medium was applied. Slides were then analysed with LEICA DM1500 fluorescent microscope with green and blue filters.

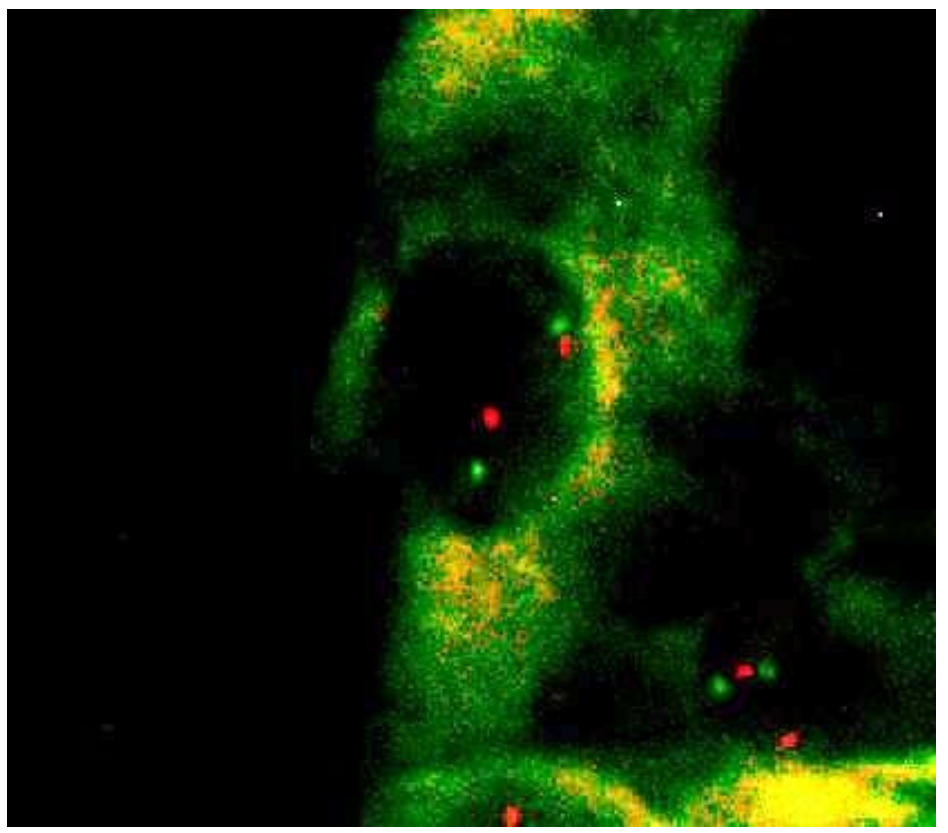

Figure 1. BRAF FISH analysis. In all tumor nuclei two signals of BRAF (smaller signal) and two signals of centromere (larger signal) were found 


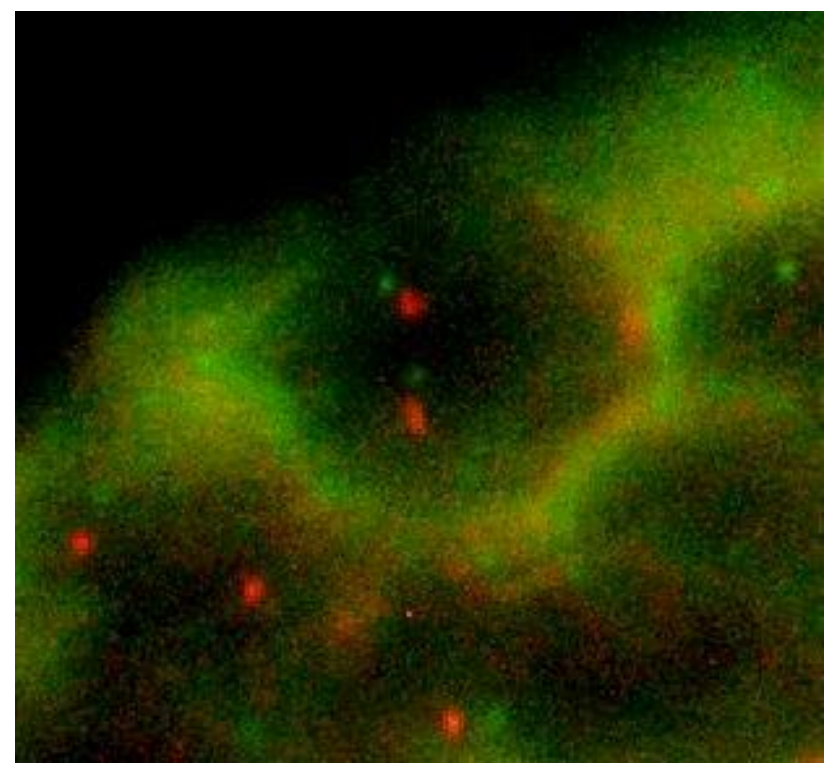

Figure 2. MYC FISH analysis. In all tumor nuclei two signals of BRAF (smaller signal) and two signals of centromere (larger signal) were found

\section{Results}

\section{Pathological features}

In all cases of papillary thyroid carcinoma, tumor cell nuclei were large, pale and crowded. Tumor cells were cytokeratin 19 positive.

\section{FISH analysis}

In all tumor nuclei two signals of BRAF and two signals of centromere were found (Figure 1). Similarly, in all tumor nuclei two signals of MYC (smaller signal) and two signals of centromere (larger signal) were found (Figure 2), indicating that BRAF and MYC gene amplifications were not found in the study group.

\section{Discussion}

The demographic and clinicopathological characteristics and molecular profile of PTCs have been changing over the past few decades. These modifications suggest changes in etiologies and risk factors of thyroid cancer that influence the tumorigenesis of PTCs (3).

The reliable tools are urgently needed to predict tumor progression and prognosis for patients with PTC. PTC is a complex disease, and both genetic and environmental factors such as iodine intake and radiation exposure are implicated in etiology of the cancer. Growing evidence has demonstrated that genetic/epigenetic factors play an important role in PTC development and treatments.

Whole exome sequencing revealed that mutational genes were mainly implicated in MAPK, PPAR, and p53 signal pathways, suggesting their functional roles in tumorigenesis of PTC (1). The MAPK/ERK pathway is activated in response to a diverse array of stimuli, such as mitogens, growth factors, and pro-inflammatory cytokines, and it regulates cell proliferation, differentiation, apoptosis, and survival. Genetic alterations in the MAPK/ERK pathway result in constitutive activation of signaling and can therefore be pro-tumorigenic. The PI3K/AKT pathway promotes cell cycle progression and is a key regulator of survival during cellular stress. Activation of growth factor receptor protein tyrosine kinases results in autophosphorylation of tyrosine residues, PI3K recruitment to the cell membrane, and allosteric activation of the catalytic subunit encoded by a gene PIK3C (2).

The majority of papillary thyroid carcinomas (PTC) are characterized by mutations in genes for components of the MAPK/ERK pathway: RET/PTC and BRAF. The BRAF gene encodes an intracellular serine-threonine kinase that phosphorylates and activates downstream targets of MAPK/ ERK signaling such as MEK. BRAF gene mutations are the most prevalent genetic alterations observed in thyroid cancer. A point mutation at nucleotide 1,799 produces a change from a valine to a glutamine at amino acid residue 600 ( BRAF V600E ) of the resulting protein that leads to constitutive BRAF dimerization and chronic activation of the MAPK pathway. Other BRAF gene mutations such as K601E, small in-frame deletions and insertions near codon 600 and even AKAP9/BRAF gene fusions, have been described, but constitute less than $2 \%$ of all mutations of this gene in a sporadic thyroid cancer (2).

The genetic signature in pediatric patients with PTC was remarkably different than that observed in adults $(7,8)$. The prevalence of the BRAF V600E mutation, the most common genetic event found in adult PTC, is significantly lower in sporadic and radiation-exposed pediatric PTC, and the aggressiveness of PTC is likely associated with other 
genetic events. RET/PTC rearrangement, the second most common event in adult PTC, is the major genetic alteration found in sporadic and radiationexposed pediatric PTC (9). Moreover, RAS mutations are a rare genetic event in pediatric PTC (8). These findings suggest that there are differences in tumor biology according to age.

The MYC protooncogene encodes a DNA-binding factor that can activate and repress transcription. Via this mechanism, MYC regulates expression of numerous target genes that control key cellular functions, including cell growth and cell cycle progression. MYC also has a critical role in DNA replication. Deregulated MYC expression resulting from various types of genetic alterations leads to constitutive MYC activity in a variety of cancers and promotes oncogenesis (10).

The results of our study indicate that BRAF and MYC genes are not amplified in PTC.
There are some limitations to our study. First, our study is limited by the inherent biases of a retrospective analysis and, therefore, the lack of a proper follow-up with all of the patients. Second, it is limited by a small sample size.

\section{Conclusion}

Although observed at a low number of patients, according to our results, amplification of BRAF and MYC genes was not involved in PTC tumorigenesis in T1 tumor stage.

\section{Acknowledgments}

The study was supported by research grants from the Faculty of Medicine, University of Niš, Serbia.

References

1. Fang $Y$, Ma $X$, Zeng J, Jin $Y$, Hu Y, Wang J, et al. The profile of genetic mutations in papillary thyroid cancer detected by whole exome sequencing. Cell Physiol Biochem 2018;50(1):169-78. [CrossRef] [PubMed]

2. Pozdeyev N, Lund G, McDermott MT. Molecular pathogenesis of thyroid cancer and oncogenes in thyroid cancer. In: Wartofsky L, Van Nostrand D, editors. Thyroid Cancer. New York: Springer; 2016.p.17-30. [CrossRef]

3. Vuong HG, Altibi AM, Abdelhamid AH, Ngoc PU, Quan VD, Tantawi MY, et al. The changing characteristics and molecular profiles of papillary thyroid carcinoma over time: a systematic review. Oncotarget 2017; 8(6):10637-49. [CrossRef] [PubMed]

4. Hong AR, Lim JA, Kim TH, Choi HS, Yoo WS, Min HS, et al. The frequency and clinical implications of the BRAF (V600E) mutation in papillary thyroid cancer patients in Korea over the past two decades. Endocrinol Metab 2014; 29:505-13. [CrossRef] [PubMed]

5. Sakr H, Chute D, Nasr C, Sturgis C. cMYC expression in thyroid follicular cell-derived carcinomas: a role in thyroid tumorigenesis. Diagn Pathol 2017;12:71. [CrossRef] [PubMed]
6. Jarząb B, Wiench M, Fujarewicz K, Krzysztof S, Jarząb M, Oczko-Wojciechowska M, et al. Gene Expression Profile of Papillary Thyroid Cancer: Sources of Variability and Diagnostic Implications. Cancer Res 2005; 65(4):1587-97. [CrossRef] [PubMed]

7. Cordioli MI, Moraes L, Carvalheira G, Sisdelli L, Alves MT, Delcelo $R$, et al. AGK-BRAF gene fusion is a recurrent event in sporadic pediatric thyroid carcinoma. Cancer Med 2016;5(7):1535-41. [CrossRef] [PubMed]

8. Cordioli MI, Moraes L, Bastos AU, Besson P, Alves MT, Delcelo $\mathrm{R}$, et al. Fusion oncogenes are the main genetic events found in sporadic papillary thyroid carcinomas from children. Thyroid 2017;27(2):182-8. [CrossRef] [PubMed]

9. Nikiforov $\mathrm{YE}$, Rowland JM, Bove KE, Monforte-Munoz $H$, Fagin JA. Distinct pattern of RET oncogene rearrangements in morphological variants of radiationinduced and sporadic thyroid papillary carcinomas in children. Cancer Res 1997;57:1690-4. [PubMed]

10. Dominguez-Sola D, Ying CY, Grandori C, Ruggiero L, Chen B, Li M, et al. Non-transcriptional control of DNA replication by c-Myc. Nature 2007;448:445-51. [CrossRef] [PubMed] 


\title{
ANALIZA GENSKIH AMPLIFIKACIJA U PAPILARNOM KARCINOMU ŠTITNE ŽLEZDE
}

\author{
Aleksandar Milićević, Dragan Mihailović, Žaklina Mijović \\ Centar za patologiju, Klinički centar Niš, Niš,Srbija \\ Kontakt: Aleksandar Milićević \\ Bulevar dr Zorana Đinđića 48, 18000 Niš, Srbija \\ E-mail: ackom88@gmail.com
}

Rak štitne žlezde najčešći je endokrini malignitet i njegova stopa je u stalnom porastu u celom svetu. Papilarni karcinom štitne žlezde (PTC) najčešći je histološki podtip karcinoma štitne žlezde, koji čini oko $75 \%$ - $85 \%$ slučajeva. Do sada su mehanizmi na kojima se temelji tumorigeneza PTC još uvek nejasni.

Procena BRAF i MYC amplifikacije gena u papilarnim karcinomima štitne žlezde izvršena je FISH analizom.

Uzorci tumorskih tkiva 10 ženskih bolesnika sa PTC analizirani su imunohistohemijski (CK19 i Ki67) i FISH analizom. FISH probe nanesene su na histološke preseke debljine $5 \mu \mathrm{m}$, prekrivene staklom i zapečaćene gumenim cementom. Nakon denaturacije na $75^{\circ} \mathrm{C}$ u trajanju od 5 minuta, sproveden je postupak hibridizacije na $37^{\circ} \mathrm{C}$ tokom 3 sata. Nakon ispiranja, primenjen je DAPI, koji sadrži medijum za montiranje.

U svim tumorskim jedrima pronađena su dva signala BRAF i dva signala MYC, što ukazuje na to da amplifikacije gena nisu nađene $u$ ispitivanoj grupi.

Iako je primećena kod malog broja bolesnika, amplifikacija BRAF i MYC gena nije bila uključena u PTC tumorigenezu T1 stadijuma tumora.

Acta Medica Medianae 2020;59(1):31-35.

Ključne reči: papilarni karcinom štitne žlezde, amplifikacija gena, $B R A F, M Y C$, imunohistohemija, T1 stadijum tumora 